Article

\title{
Variability and Correlations among Groundnut Populations for Early Leaf Spot, Pod Yield, and Agronomic Traits
}

\author{
Adama Zongo 1,2, Abel T. Nana ${ }^{2}$, Mahamadou Sawadogo ${ }^{2}$, Abdourasmane K. Konate ${ }^{3}$, \\ Philippe Sankara ${ }^{2}$, Bonny R. Ntare ${ }^{1}$ and Haile Desmae ${ }^{1, *}$ \\ 1 International Crops Research Institute for the Semi-Arid Tropics (ICRISAT), BP 320 Bamako, Mali; \\ zongoadama87@gmail.com (A.Z.); bntare@gmail.com (B.R.N.) \\ 2 Life and Earth Sciences Department, University Ouaga I Pr. Joseph Ki-Zerbo, \\ BP 7021 Ouagadougou, Burkina Faso; nt.abel@yahoo.fr (A.T.N.); \\ sawadogomahamadou@yahoo.fr (M.S.); philippe.sankara@ird.fr (P.S.) \\ 3 Institut de l'Environnementet de Recherches Agricoles (INERA), BP 910 Bobo-Dioulasso, Burkina Faso; \\ kadougoudiou@gmail.com \\ * Correspondence: h.desmae@ecgiar.org; Tel.: +223-7117-8098
}

Academic Editor: Jacqueline Batley

Received: 9 May 2017; Accepted: 28 July 2017; Published: 5 August 2017

\begin{abstract}
The present experiment was conducted in Mali to study the genetic variability and correlation of early leaf spot (ELS) resistance parameters and agro-morphological traits in groundnut using two F3 populations from crosses QH243C X NAMA and TS32-1 X NAMA. Estimates of genotypic coefficient of variation and phenotypic coefficient of variation revealed high value for pod yield, kernel yield, and ELS score at 60 and 80 days after sowing for the cross QH243C X NAMA. Low-to-moderate GCV and PCV were obtained for the remaining traits for both crosses. High heritability values coupled with high genetic advance as percentage of mean recorded for ELS_II, defoliation percent, pod yield in cross QH243C X NAMA; shelling percent for the cross TS32-1 X NAMA and ELS_III; and plant height, kernel yield in both crosses, indicate the significant role of additive gene action for inheritance of these traits. Correlation analysis indicated that pod and kernel yield were significant and positively correlated with 100 kernel weight and shelling percent. For cross QH243C X NAMA, kernel yield showed significant positive correlation with all ELS resistance components but the correlation was not significant for the cross TS32-1 X NAMA. Positive and significant correlation was observed between ELS resistance components themselves, suggesting that these components could be controlled by a similar polygenic system. The findings suggest that early generation selection should be effective for days to first flowering, days to 50\% flowering, plant height, pod yield, kernel yield, 100 kernel weight and early leaf spot resistance which recorded the highest value of heritability in the two crosses.
\end{abstract}

Keywords: genetic variability; correlation; agronomical traits; early leaf spot; groundnut

\section{Introduction}

Groundnut (Arachis hypogaea L.), an annual leguminous crop, is one of the important oil seed crops in the world. It is a rich source of protein. Groundnut seed contains about $45-55 \%$ oil and $27-33 \%$ of protein [1]. Its seeds are also a source of minerals and vitamins like vitamin E, niacin, falcin, calcium, phosphorus, magnesium, zinc, iron, riboflavin, thiamine, and potassium [2]. In addition, the haulm is used as animal feed and industrial raw material. Groundnut also contributes to maintaining soil fertility by fixing atmospheric nitrogen. 
In 2014, groundnut was grown in more than 115 countries around the world, covering a total area of about 24.31 million (M) hectares (ha) with a global production of about 42.4 million tons [3]. The major producers were China and India with $15.7 \mathrm{M}$ and $6.5 \mathrm{M}$ tons, respectively, followed by Nigeria (3.4 $\mathrm{M}$ tons), the USA (2.4 M tons), and Sudan (1.8 M tons). Continent-wide, Africa ranks second accounting for over $29.8 \%$ of global production after Asia (59.8\% of global production). However, Africa has the lowest average yield (964.8 kg/ha) compared to America (3333.4 kg/ha), Asia (2370.6 kg/ha), Oceania (1847.9 kg/ha), Europe (1158.5 kg/ha), and global average yield (1654.6 $\mathrm{kg} / \mathrm{ha}$ ). Several constraints like abiotic stress (e.g., drought) and biotic stress (e.g., diseases and pests) can explain the low productivity of groundnut in Africa.

Among the main foliar fungal diseases, early leaf spot (ELS) caused by Cercospora arachidicola Hori and late leaf spot (LLS) caused by Phaeoisariopsis personata (Bert and Curtis) Deigton are the more destructive diseases $[4,5]$. The two diseases combined can cause pod and fodder yield loss of over $50 \%$ to 70\% [6,7]. In West Africa, yield loss due to ELS alone reaches up to 70\% [8]. Development of high yielding cultivars with resistance to these diseases, particularly ELS, is an important breeding priority to reduce impact of disease and increase groundnut production in West Africa. Understanding the genetic underpinnings of early leaf spot resistance components and agronomic traits (yield and its components) is likely to contribute to enhancing breeding for these traits.

Effectiveness of selection is dependent upon the availability of large genetic variability present in the breeding material for the target character and the extent to which it is heritable $[9,10]$. It also depends on the direction and magnitude of association between the traits to be improved [11]. Therefore, plant breeders need to have a good knowledge about genetic variability-i.e., genotypic coefficient of variation (GCV), phenotypic coefficient of variation (PCV), heritability in broad sense, genetic advance (GA), and genetic advance as percentage of mean (GAM)—and good understanding of correlation between the traits to be improved for the genetic material at hand. To this effect, the objective of the present study was to assess genetic variability of two F3 populations of groundnut based on ELS resistance components, agro-morphological traits (agronomic yield and yield components) and evaluate the relationships between these traits.

\section{Results}

\subsection{Analysis of Variance}

The results of analysis of variance for the measured characters are presented in Table 1. In the analysis of variance for all agro-morphological traits, the three stages of ELS and defoliation percent due to ELS effect in the two F3 populations revealed significant difference $(p<0.05)$ for all the traits except ELS score at 60 DAS (ELS_II) for the cross TS32-1 X NAMA. This indicated the presence of variability in the genetic materials for the traits studied.

The susceptible parents QH243C and TS32-1 had an average disease score of 7.35 and 8.052 at 80 days after sowing (ELS_III), while the resistant parent (NAMA) had an average disease score of 2.93 and 3.094 in crosses QH243C X NAMA and TS32-1 X NAMA, respectively. The susceptible and resistant parents also differed significantly in terms of infestation progress for ELS score at 60 (ELS_II) and 80 days after sowing (ELS_III). In a span of 20 days, the disease score for QH243C and TS32-1 increased from 4.32 to 7.35 and from 3.63 to 8.05 , while that of the resistant parent (NAMA) rose from 2.02 to 2.93 and from 2.07 to 3.09 in crosses QH243C X NAMA and TS32-1 X NAMA, respectively. The two F3 populations significantly differed for all agro-morphological traits. The F3 population from cross QH243C X NAMA was distinct for its highest mean value for all agro-morphological traits including pod and kernel yield and its lowest mean value for the three stages of ELS incidence, whereas the one from TS32-1 X NAMA showed low mean for the agro-morphological traits and relatively higher value for ELS score. 
Table 1. Mean performance of parents and F3 populations for ELS scores and agro-morphological trait.

\begin{tabular}{|c|c|c|c|c|c|c|c|c|c|c|c|c|}
\hline Crosses & Source of Variation & DFF & D50F & ELS_I & ELS_II & ELS_III & PH & Defol\% & Pyield & Kyield & Sh $\%$ & $100 \mathrm{KW}$ \\
\hline \multirow{6}{*}{ QH243C X NAMA } & NAMA & 29.65 & 34.01 & 2.00 & 2.02 & 2.93 & 26.13 & 23.94 & 739.28 & 558.01 & 50.46 & 22.29 \\
\hline & $\mathrm{QH} 243 \mathrm{C}$ & 25.01 & 26.73 & 2.33 & 4.32 & 7.35 & 40.63 & 31.26 & 2360.37 & 1571.89 & 62.62 & 28.99 \\
\hline & F3pop & 25.66 & 28.13 & 2.33 & 2.91 & 5.04 & 38.53 & 32.23 & 2409.20 & 1261.72 & 60.66 & 31.48 \\
\hline & Range & $21-33$ & $24-34$ & $2-3$ & $2-5$ & $3-8$ & $8-50$ & $14.38-59.54$ & $691.70-4387$ & $514.60-2324$ & 20-95 & $15-53$ \\
\hline & Fproba & $* *$ & $* *$ & $*$ & $* *$ & $* *$ & $* *$ & $* *$ & $* *$ & $* *$ & $*$ & $* *$ \\
\hline & $\mathrm{CV} \%$ & 7.7 & 6.78 & 13 & 23.17 & 26.31 & 18.24 & 16.08 & 22.97 & 20.66 & 10.76 & 12.78 \\
\hline \multirow{6}{*}{ TS32-1 X NAMA } & NAMA & 27.78 & 32.29 & 2.00 & 2.07 & 3.09 & 23.14 & 30.86 & 782 & 369.99 & 58.29 & 23.62 \\
\hline & TS32-1 & 23.39 & 25.74 & 2.33 & 3.63 & 8.05 & 38.42 & 51.78 & 1324 & 751.61 & 53.5 & 29.73 \\
\hline & F3pop & 23.9 & 26.40 & 2.50 & 2.97 & 5.44 & 35.58 & 50.39 & 2111.25 & 1089.12 & 57.42 & 30.40 \\
\hline & Range & $20-32$ & $24-34$ & $2-3$ & $2-6$ & $3-8$ & $6.66-50$ & $16.67-84.87$ & $830-5099$ & $269.8-2614$ & $10-96$ & $14-53$ \\
\hline & Fproba & $* *$ & $* *$ & $* *$ & ns & $* *$ & $* *$ & $* *$ & $* *$ & $* *$ & $* *$ & $* *$ \\
\hline & CV\% & 6.65 & 6.26 & 13.94 & 5.84 & 21.28 & 20.96 & 13.35 & 26.12 & 32.76 & 18.18 & 11.93 \\
\hline
\end{tabular}

DFF: days to first flowering, D50F: days to 50 percent flowering, PH: plant height, Sh\%: shelling percent, 100 KW: 100 kernel weight, Pyield: pod yield, Kyield: kernel yield, ELS_I: early leaf spot score at 40 days after sowing, ELS_II: early leaf spot score at 60 days after sowing, ELS_III: early leaf spot score at 80 days after sowing, Defol\%: defoliation percent, *: significant at $0.05, * *$ significant at 0.01 , ns: no significance. 


\subsection{Estimation of Genetic Variability Parameters}

The genotypic $(\mathrm{Vg})$ and phenotypic variance $(\mathrm{Vp})$, genotypic $(\mathrm{GCV})$ and phenotypic coefficient of variation $(\mathrm{PCV})$, broad sense heritability $\left(\mathrm{H}^{2}\right)$, and genetic advance as percent of mean (GAM) for all the traits studied are presented in Table 2. Genotypic variances ranged from 0.03 (ELS_I) to 176,529 (pod yield) and from 0.001 (ELS_II) to 48,847 (pod yield) in crosses QH243C X NAMA and TS32-1 X NAMA, respectively. For phenotypic variance, the minimum value was recorded for ELS_I (0.09) and ELS_II (0.02) in crosses QH243C X NAMA and TS32-1 X NAMA and the maximum for pod yield in both crosses $(276,560.3$ and 72,159$)$. Almost all traits related to ELS resistance (ELS_I, ELS_II and ELS_III) presented low genotypic and phenotypic variances, except defoliation percent in both crosses.

Table 2. Genetic variability parameters for different traits in $\mathrm{F}_{3}$ population of a groundnut.

\begin{tabular}{|c|c|c|c|c|c|c|c|c|}
\hline \multicolumn{9}{|c|}{ Cross QH243 X NAMA } \\
\hline Variable & Mean & $\mathrm{Vg}$ & $\mathrm{Vp}$ & GCV & PCV & $\mathrm{H}^{2}(\%)$ & GA & GAM \\
\hline DFF & 25.71 & 3.3 & 3.81 & 7.07 & 7.59 & 86.73 & 3.49 & 13.56 \\
\hline $\mathrm{D} 50 \mathrm{~F}$ & 28.19 & 3.24 & 3.64 & 6.38 & 6.77 & 88.98 & 3.5 & 12.4 \\
\hline ELS_I & 2.33 & 0.03 & 0.09 & 7.87 & 13.16 & 35.77 & 0.23 & 9.7 \\
\hline ELS_II & 2.93 & 0.31 & 0.46 & 19.03 & 23.19 & 67.36 & 0.94 & 32.17 \\
\hline ELS_III & 5.04 & 1.49 & 1.79 & 24.18 & 26.56 & 82.85 & 2.29 & 45.34 \\
\hline $\mathrm{P} \overline{\mathrm{H}}$ & 38.41 & 42.2 & 49.25 & 16.91 & 18.27 & 85.69 & 12.39 & 32.25 \\
\hline Defoliation \% & 32.12 & 16.54 & 26.01 & 12.66 & 15.88 & 63.60 & 6.68 & 20.8 \\
\hline PYield (kg/ha) & 2387.72 & 176,529 & $276,560.3$ & 17.6 & 22.02 & 63.83 & 691.49 & 28.96 \\
\hline Kyield (kg/ha) & 1256.74 & 82,476 & $108,412.7$ & 22.85 & 26.2 & 76.08 & 516.01 & 41.06 \\
\hline Shelling\% & 60.56 & 17.71 & 40.35 & 6.95 & 10.49 & 43.89 & 5.74 & 9.48 \\
\hline $100 \mathrm{KW}(\mathrm{g})$ & 31.34 & 11.06 & 15.43 & 10.61 & 12.53 & 71.68 & 5.8 & 18.51 \\
\hline \multicolumn{9}{|c|}{ Cross TS32-1 X NAMA } \\
\hline DFF & 23.95 & 1.91 & 1.96 & 5.76 & 5.85 & 97.08 & 2.80 & 11.70 \\
\hline D50F & 26.47 & 2.24 & 2.29 & 5.66 & 5.72 & 97.98 & 3.05 & 11.54 \\
\hline ELS_I & 2.50 & 0.03 & 0.04 & 6.80 & 7.62 & 79.70 & 0.31 & 12.51 \\
\hline ELS_II & 2.97 & 0.001 & 0.02 & 1.90 & 4.96 & 14.72 & 0.04 & 1.50 \\
\hline ELS_III & 5.45 & 0.64 & 0.69 & 14.64 & 15.28 & 91.69 & 1.57 & 28.87 \\
\hline $\mathrm{PH}$ & 35.46 & 42.58 & 43.48 & 18.40 & 18.60 & 97.93 & 13.30 & 37.51 \\
\hline Defoliation\% & 50.18 & 23.45 & 25.78 & 9.65 & 10.12 & 90.97 & 9.51 & 18.96 \\
\hline PYield (kg/ha) & 2085.00 & 48,847 & 72,159 & 10.60 & 12.88 & 67.69 & 374.59 & 17.97 \\
\hline Kyield (kg/ha) & 1076.24 & 34,357 & $39,948.33$ & 17.22 & 18.57 & 86.00 & 354.11 & 32.90 \\
\hline Shelling\% & 57.39 & 37.40 & 42.60 & 10.66 & 11.37 & 87.79 & 11.80 & 20.57 \\
\hline $100 \mathrm{KW}(\mathrm{g})$ & 30.32 & 3.97 & 4.66 & 6.57 & 7.12 & 85.25 & 3.79 & 12.50 \\
\hline $\begin{array}{l}\text { DFF: days to firs } \\
100 \text { KW: } 100 \text { ker } \\
\text { sowing, ELS_II: } \\
\text { Defoliation\%: de } \\
\text { of variance, PCV } \\
\text { genetic advance }\end{array}$ & $\begin{array}{l}\text { ering, D } \\
\text { eight, Py }\end{array}$ & $\begin{array}{l}\text { g: genoty } \\
\text { ient of va }\end{array}$ & ic variance, & p: phe & pic va & Shellir & notypic & $\begin{array}{l}\text { sercent, } \\
\text { ys after } \\
\text { sowing, } \\
\text { fficient } \\
\text { GAM: }\end{array}$ \\
\hline
\end{tabular}

Genotypic coefficient of variance (GCV) varied from 6.38 (D50F) to 24.18 (ELS_III) and phenotypic coefficient of variance (PCV) varied from 6.77 (D50F) to 26.56 (ELS_III) in the cross QH243C X NAMA (Table 2). For cross TS32-1 X NAMA, the maximum values of GCV and PCV were recorded for plant height (18.40 and 18.60) and the minimum values for ELS_II (1.90 and 4.96). High GCV and PCV (>20\%) were observed only in the cross QH243C X NAMA for ELS_II, ELS_III, kernel yield and pod yield. Moderate estimates of PCV and GCV were observed for $100 \mathrm{KW}$ in the cross QH243C X NAMA; ELS_III, pod yield, and kernel yield in the cross TS32-1 X NAMA; and plant height, defoliation percent, and shelling percent in both crosses. The days to first flowering (DFF), days to $50 \%$ flowering (D50F), and ELS score at 40 days after sowing (ELS_I) recorded low value $(<10 \%)$ of GCV and PCV in the two crosses. GCV and PCV estimates for all traits were higher in the cross QH243C X NAMA relative to cross TS32-1 X NAMA. In addition, PCV estimates were higher than GCV estimates for all the traits in both crosses. However, the magnitude of difference was low for all the traits. 
Broad sense heritability $\left(\mathrm{H}^{2}\right)$ represents the relative strength of the traits and indicates the efficiency of selection systems [10]. $\mathrm{H}^{2}$ estimates varied from $35.77 \%$ (ELS_I) to $88.98 \%$ (D50F) in the cross QH243C X NAMA and from 14.72 (ELS_II) to $97.98 \%$ (D50F) in the cross TS32-1 X NAMA. High $\mathrm{H}^{2}(>60 \%)$ was observed for the days to first flowering ( $86.77 \%$ and $\left.97.08 \%\right)$, days to $50 \%$ flowering (88.98\% and $97.98 \%)$, ELS_III (82.85\% and $91.69 \%)$, plant height (85.69\% and $97.93 \%)$, defoliation percent $(63.60 \%$ and $90.97 \%)$, pod yield $(63.83 \%$ and $67.69 \%)$, kernel yield $(76.08 \%$ and $86 \%)$, and 100 kernel weight $(71.68 \%$ and $85.25 \%)$ in the crosses QH243C X NAMA and TS32-1 X NAMA, respectively. Moderate $\mathrm{H}^{2}(30-60 \%)$ was recorded for ELS score at 40 days after sowing (ELS_I) and shelling percent in the cross QH243C X NAMA with $35.25 \%$ and $43.89 \%$, respectively. Low $\mathrm{H}^{2}(14.72 \%)$ was recorded for ELS score at 60 days after sowing (ELS_II) in the cross TS32-1 X NAMA. Contrary to GCV and PCV estimates, $\mathrm{H}^{2}$ values were high in the cross TS32- 1 X NAMA compared to $\mathrm{H}^{2}$ in the cross QH243C X NAMA for all traits studied except ELS score at 60 days after sowing (ELS_II).

Genetic advance (GA) estimates ranged from 0.23 for ELS_I to 691.49 for pod yield in the cross QH243C X NAMA and from 0.04 for ELS_II to 374.59 for pod yield in the cross TS32-1 X NAMA. The highest GA was recorded for pod yield and kernel yield in both crosses. For genetic advance as percent of mean (GAM), high (>20\%) values were recorded for ELS_II $(32.17 \%)$, defoliation percent (20.80\%), and pod yield (28.96\%) in the cross QH243C X NAMA; shelling percent (20.57\%) in the cross TS32-1 X NAMA; and ELS_III (45.34\% and 28.87\%), plant height (32.25\% and 37.51\%), and kernel yield $(41.06 \%$ and $32.90 \%)$ in both crosses. Moderate GAM (10-20\%) was observed for the remaining traits except ELS_I (9.7\%) and shelling percent $(9.48 \%)$ in the cross QH243C X NAMA and ELS_II $(1.50 \%)$ in cross TS32-1 X NAMA.

\subsection{Correlation}

Results of correlation analysis between all agro-morphological traits and ELS resistance parameters in the two crosses (QH243C X NAMA and TS32-1 X NAMA) are presented in Table 3. Days to $50 \%$ flowering showed significant and negative correlation with all traits except with days to first flowering in both crosses. Shelling percent and ELS resistance parameters (ELS_I, ELS_II, ELS_III, and defoliation percent) showed positive correlation with all traits except with days to first flowering and days to $50 \%$ flowering in the two crosses. Pod yield showed positive correlation with kernel yield $(r=0.8661$ and $r=0.7648), 100$ kernel weight $(r=0.475$ and $r=0.1125)$ and shelling percent $(r=0.3223$ and $r=0.0486$ ) in both crosses. For cross QH243C X NAMA, kernel yield showed significant positive correlation with all ELS resistance components $\left(r=0.29^{* *}\right.$ with ELS_I, $r=0.36^{* *}$ with ELS_II, $r=0.48^{* *}$ with ELS_III) but the correlation was not significant for the cross TS32-1 X NAMA. All components of ELS resistance were positively correlated among themselves in the two crosses. Correlation of plant height in cross QH243C X NAMA with 100 kernel weight $(r=0.2463)$ and kernel yield $(r=0.3948)$ were significant and positive, while in cross TS32-1 X NAMA these correlations were not significant and took negative direction ( $r=-0.0157$ and $r=-0.0448$, respectively). 
Table 3. Correlation coefficients among agro-morphological traits and ELS resistance parameters for two crosses.

\begin{tabular}{|c|c|c|c|c|c|c|c|c|c|c|}
\hline Traits & D50F & $\mathrm{Sh} \%$ & Defol\% & ELS_I & ELS_II & ELS_III & DFF & PH & $100 \mathrm{KW}$ & Pyield \\
\hline \multicolumn{11}{|c|}{ Cross QH243C X NAMA } \\
\hline D50F & - & & & & & & & & & \\
\hline $\mathrm{Sh} \%$ & $-0.45^{* *}$ & - & & & & & & & & \\
\hline Defol\% & $-0.55^{* *}$ & $0.17 \mathrm{~ns}$ & - & & & & & & & \\
\hline ELS_I & $-0.29 * *$ & $0.15 \mathrm{~ns}$ & $0.29^{*}$ & - & & & & & & \\
\hline ELS_II & $-0.43^{* *}$ & $0.15 \mathrm{~ns}$ & $0.56^{* *}$ & $0.54 * *$ & - & & & & & \\
\hline ELS_III & $-0.65^{* *}$ & $0.30 *$ & $0.66^{* *}$ & $0.37^{* *}$ & $0.75^{* *}$ & - & & & & \\
\hline DFF & 0.93 ** & -0.43 ** & $-0.56^{* *}$ & $-0.30 *$ & $-0.46^{* *}$ & $-0.66^{* *}$ & - & & & \\
\hline PH & $-0.51^{* *}$ & $0.39 * *$ & $0.50^{* *}$ & $0.43^{* *}$ & $0.64^{* *}$ & $0.75^{* *}$ & $-0.57 * *$ & - & & \\
\hline $100 \mathrm{KW}$ & $-0.29 * *$ & $0.43 \mathrm{~ns}$ & $0.06 \mathrm{~ns}$ & $0.34^{* *}$ & $0.21 \mathrm{~ns}$ & $0.11 \mathrm{~ns}$ & $-0.24 *$ & $0.25 *$ & - & \\
\hline Pyield & $-0.63 * *$ & $0.32 \mathrm{~ns}$ & $0.15 \mathrm{~ns}$ & $0.31^{* *}$ & $0.36^{* *}$ & $0.40^{* *}$ & $-0.55^{* *}$ & $0.36^{* *}$ & $0.47^{* *}$ & - \\
\hline Kyield & $-0.61 * *$ & $0.45 \mathrm{~ns}$ & $0.20 \mathrm{~ns}$ & $0.29 * *$ & $0.36^{* *}$ & $0.48^{* *}$ & $-0.54^{* *}$ & $0.39^{* *}$ & $0.47^{* *}$ & $0.87^{* *}$ \\
\hline \multicolumn{11}{|c|}{ Cross TS32-1 X NAMA } \\
\hline D50F & - & & & & & & & & & \\
\hline $\mathrm{Sh} \%$ & $-0.46^{* *}$ & - & & & & & & & & \\
\hline Defol\% & $-0.38^{* *}$ & $0.39 * *$ & - & & & & & & & \\
\hline ELS_I & $-0.42 * *$ & $0.25^{*}$ & $0.42 * *$ & - & & & & & & \\
\hline ELS_II & $-0.46^{* *}$ & $0.12 \mathrm{~ns}$ & $0.26^{*}$ & $0.19 \mathrm{~ns}$ & - & & & & & \\
\hline ELS_III & $-0.56^{* *}$ & $0.41^{* *}$ & $0.48^{* *}$ & 0.52 ** & $0.35^{* *}$ & - & & & & \\
\hline DFF & $0.89^{* *}$ & $-0.38^{* *}$ & $-0.37^{* *}$ & $-0.38^{* *}$ & $-0.39 * *$ & $-0.51 * *$ & - & & & \\
\hline $\mathrm{PH}$ & $-0.58^{* *}$ & $0.39 * *$ & $0.47^{* *}$ & $0.44^{* *}$ & $0.28 *$ & $0.55^{* *}$ & -0.63 ** & - & & \\
\hline $100 \mathrm{KW}$ & $-0.22 *$ & $0.24 *$ & $0.27^{*}$ & $0.004 \mathrm{~ns}$ & $0.22 \mathrm{~ns}$ & $0.06 \mathrm{~ns}$ & $-0.22 \mathrm{~ns}$ & $-0.02 \mathrm{~ns}$ & - & \\
\hline Pyield & $-0.31 * *$ & $0.05 \mathrm{~ns}$ & $0.16 \mathrm{~ns}$ & $0.19 \mathrm{~ns}$ & $0.11 \mathrm{~ns}$ & $0.30^{* *}$ & $-0.21 \mathrm{~ns}$ & $0.02 \mathrm{~ns}$ & $0.11 \mathrm{~ns}$ & - \\
\hline Kyield & $-0.38^{* *}$ & $0.22 \mathrm{~ns}$ & $0.15 \mathrm{~ns}$ & $0.13 \mathrm{~ns}$ & $0.18 \mathrm{~ns}$ & $0.15 \mathrm{~ns}$ & $-0.22 *$ & $-0.05 \mathrm{~ns}$ & $0.10 \mathrm{~ns}$ & $0.76^{* *}$ \\
\hline
\end{tabular}

DFF: days to first flowering, D50F: days to 50 percent flowering, PH: plant height, Sh\%: shelling percent, $100 \mathrm{KW:}$ 100 kernel weight, Pyield: pod yield, Kyield: kernel yield, ELS_I: early leaf spot score at 40 days after sowing, ELS_II: early leaf spot score at 60 days after sowing, ELS_III: early leaf spot score at 80 days after sowing, Defol\%: defoliation percent, *: significant at $0.05,{ }^{* *}$ : significant at 0.01, ns: no significant.

\section{Discussion}

In the present study, significant differences among the F3 progenies in the two crosses were observed for all the traits indicating the presence of genetic variability for disease score and agronomic traits in the populations. High variability values for these traits were previously reported including leaf spot disease resistance [12-14] in F2 populations; and days to first flowering, days to 50\% flowering, pod yield, kernel yield, shelling percent, and 100 kernel weight in cultivated groundnut $[2,12,15,16]$.

Estimation of GCV and PCV revealed high value for kernel yield, pod yield and ELS score at 60 and 80 days after sowing (ELS_II and ELS_III) in cross QH243C X NAMA, suggesting the presence of considerable variation among the population. Similar findings of higher estimates of GCV and PCV were reported for kernel yield and pod yield [2,9,10,15,17-19], ELS score at 60 and 80 days after sowing [13,14,18,20-23]. Moderate PCV and GCV were observed for 100 kernel weight (cross QH243C X NAMA); pod yield, kernel yield, and ELS score at 80 days after sowing (cross TS32-1 X NAMA), plant height, shelling percent, and defoliation percent (in both crosses) indicating presence of moderate levels of variability for these traits in the populations. These results are similar to the findings of Maurya et al. [24] and Patil et al. [25] for plant height and shelling percent, and Hamasselbe et al. [22] for defoliation percent. Days to 50\% flowering and days to first flowering showed low GCV and PCV, indicating the presence of narrow genetic variability for these traits. These results are in accordance with previous findings $[10,18,26,27]$. The difference between PCV and GCV was small, indicating low effect of environment on the expression of these traits.

Most of the traits studied were highly heritable as indicated by high broad sense heritability estimates. Heritability estimates for ELS resistance were consistent over the two crosses and were generally high for all scores (ELS_I, ELS_II, ELS_III, and defoliation percent) indicating that selection based on ELS score and defoliation percent would be useful for ELS resistance. These results also indicate a high response to selection for ELS resistance due to reduced environment influence in these crosses. Similar findings were obtained for ELS score $[18,23,28]$ and for ELS score and defoliation 
percent [22]. The authors concluded that individual plant selection for early and late leaf spot diseases would be effective in early generations. High heritability was also obtained for the agro-morphological traits like days to first flowering, days to $50 \%$ flowering, plant height, pod yield, kernel yield, and 100 kernel weight in both crosses. Similar results were also reported for days to first flowering, days to $50 \%$ flowering and plant height $[9,15]$, for pod yield and kernel yield $[10,15,29]$, and for pod yield and 100 kernel weight [18].

Broad sense heritability is an important parameter for breeding. It provides useful information on genetic variability, however, when coupled with genetic advance as a percent of mean it provides a better prediction of expected gain under selection than heritability alone. Estimates of both parameters help to understand the type of gene action involved in the expression of traits studied, particularly for polygenic traits. High heritability values coupled with high GAM were recorded for ELS_II, defoliation percent, pod yield in cross QH243C X NAMA; shelling percent in cross TS32-1 X NAMA; and ELS_III, plant height, kernel yield in both crosses. In addition, high heritability values with moderate GAM were obtained for ELS_I, pod yield in cross TS32-1 X NAMA and for days to first flowering, days to $50 \%$ flowering, 100 kernel weight in the two crosses. This indicates a significant role of additive gene action for inheritance of these traits. Classical selection methods would be effective for improvement of these traits including ELS resistance from these crosses. Similar results were reported for plant height, pod yield, kernel yield [10,25], days to first flowering, days to 50\% flowering [9,21,26], and ELS resistance $[13,14,18]$. Moderate heritability values coupled with low GAM were obtained in cross QH243C X NAMA for shelling percent. This indicates that additive and non-additive gene effects are playing an important role in the expression of this character. Therefore, selection for this character is not effective in early segregating generations. This finding is in agreement with previous results [14]. The correlation analysis in the present study revealed significant and negative correlation between flowering parameters (days to first flowering and days to $50 \%$ flowering) with pod yield and kernel yield in the two crosses, suggesting that early flowering and high yield could be simultaneously selected. These results are in accordance with previous results [30,31]. Pod yield presented a positive correlation with kernel yield, 100 kernel weight, and shelling percent in both crosses, indicating a favorable association between yield and its components. Similar findings were also previous reported $[9,13]$. In the two crosses, ELS resistance parameters were positively and significantly associated among themselves. These results suggest that all ELS resistance parameters could be controlled by a similar polygenic system. Early research reported similar results for ELS components [20] and leaf spot diseases including ELS [18,31]. Correlations between ELS resistance parameters and kernel yield and its components were positive in cross QH243C X NAMA, revealing the linkage of high productivity with ELS susceptibility. These results are in agreement with [13,22,31]. Several studies revealed the possibility of breaking undesirable linkages between yield and diseases susceptibility by reshuffling of genes through multiple crosses [32]. ELS resistance combined with high yield could be bred through back crossing in multiple ways. Plant height presented a positive correlation with pod and kernel yield in cross QH243C X NAMA, whereas these correlations were negative in cross TS32-1 X NAMA, suggesting the possibility of identifying desirable recombinants in one of the crosses.

\section{Materials and Methods}

\subsection{Study Area}

The study was carried out in 2014 at ICRISAT West Africa Regional hub Research Station based at Samanko in Mali. Samanko is located at $25 \mathrm{~km}$ from Bamako near Niger River. The station is located between $12^{\circ} 54^{\prime} \mathrm{N}$, and $8^{\circ} 4^{\prime} \mathrm{W}$ at an altitude of $330 \mathrm{~m}$ above sea level. 


\subsection{Breeding Population}

Two Spanish bunch ELS susceptible varieties (i.e., QH243C and TS32-1) obtained from INERA and resistant local cultivar (NANA - a Virginia bunch) grown in Burkina Faso were used as parents to develop two populations (Pop1 = QH243 X NAMA and Pop2 = TS32-1 X NAMA). The F3 populations of the two crosses, comprised of 82 individuals per population, were used for early leaf spot resistance and agronomic trait evaluations.

\subsection{Experimental Design and Traits Measured}

The two F3 populations with 82 individuals each were grown in two different trials during the 2014 rainy season. Each entry was sown in one row of $4 \mathrm{~m}$ length by adopting spacing of $50 \times 15 \mathrm{~cm}$ in an augmented design with three replications for checks. Seeds were treated using a fungicide (APRON STAR 42 WS) before sowing. The screening of the progenies and their parental lines was carried out under natural infestation. Samanko station is a hotspot for leaf spot diseases including ELS. Normal cultural practices were followed during the growing season. Observations were recorded for seven agro-morphological traits viz., days to first flowering (DFF, days after sowing), days to 50 percent flowering (D50F, days after sowing), plant height ( $\mathrm{PH}, \mathrm{cm})$, shelling percent $(\mathrm{Sh} \%), 100$ kernel weight (100 KW, g), pod yield (Pyield, kg/ha), and kernel yield (Kyield, kg/ha). Also, at 40 days (ELS_I), 60 days (ELS_II), and 80 days (ELS_III) after planting, ELS incidence was scored using the 9-point field scale of ICRISAT [33]. Score of 1 was given if there was $0 \%$ infection; 2 for $1-5 \%$; 3 for $6-10 \% ; 4$ for $11-20 \%$, 5 for $21-30 \%$; 6 for $31-40 \%$; 7 for $41-60 \%$; 8 for $61-80 \%$; and 9 for $81-100 \%$ infection. According to Pande and Rao [34], genotypes with a disease score of 1 to 3, 4 to 6 and 7 to 9 were designated as being resistant, tolerant, and susceptible, respectively. In addition, to evaluate the incidence of ELS in the F3 progenies, we also estimated the defoliation percent (Defol\%) at 80 days after sowing. It was computed as follows based on the main stem of 10 plants

$$
\text { Defoliation percent }=\frac{\text { Number of leaflets lost }}{\text { Total leaflets }} \times 100
$$

\subsection{Statistical Analysis}

Analysis of variance (ANOVA) was carried out on the agro-morphological traits and ELS incidence parameters to access the genotype effect for all traits using Genstat 14th edition. Phenotypic and genotypic coefficients of variance were estimated according to Burton [35] to quantify the genetic variance among the genotypes. The heritability in broad sense and genetic advance as a percent of mean were estimated using the formula given by Johnson et al. [36] and Burton and De Van [37], respectively.

Phenotypic and genotypic variances were estimated using the formula

$$
\begin{gathered}
V_{g}=\frac{M S_{g}-M S_{e}}{r} \\
V_{p}=V_{g}+M S_{e}
\end{gathered}
$$

$V g=$ genotypic variance; $V p=$ phenotypic variance; $M S g=$ mean square of genotypes, $M S e=$ mean square of error; and $r=$ number of replications.

$$
\begin{aligned}
& G C V=\frac{\sqrt{V_{g}}}{X} \times 100 \\
& P C V=\frac{\sqrt{V_{p}}}{X} \times 100
\end{aligned}
$$

$G C V=$ genotypic coefficient of variability; $P C V=$ phenotypic coefficient of variability; $\sqrt{V_{g}}=$ genotypic standard deviation; $\sqrt{V_{p}}=$ phenotypic standard deviation; and $\mathrm{X}=$ general mean of the character. 
Heritability in broad sense $\left(H^{2}\right)$ was computed as the ratio of genetic $(V g)$ variance to the total phenotypic variance $(V p)$.

$$
\begin{gathered}
H^{2}=\frac{V_{g}}{V_{p}} \times 100 \\
G A=H^{2} k \sqrt{V_{p}} \\
G A M=\frac{G A}{X} \times 100
\end{gathered}
$$

$G A=$ genetic advance; $G A M=$ genetic advance as percent of mean; $k=$ Selection differential, which is equal to 2.06 at $5 \%$ intensity of selection; $X=$ general mean of the character.

Correlation analysis among all the traits studied was computed using Genstat 14th edition.

\section{Conclusions}

The present study indicated that most of traits were under influence of genetic control and could be improved through classical selection. Results suggest that early generation selection should be effective for days to first flowering, days to $50 \%$ flowering, plant height, pod yield, kernel yield, 100 kernel weight, and early leaf spot resistance which recorded highest value of heritability in the two crosses.

Acknowledgments: The authors are thankful to all the team of Groundnut Breeding program, ICRISAT-WCA, and the team of Biosciences Laboratory, University Ouaga I Pr. Joseph Ki-Zerbo of Ouagadougou. Financial support from Tropical Legume II (TL-II) of Bill and Melinda Gates Foundation (BMGF), USA is duly acknowledged.

Author Contributions: A.Z. conducted the experiment, collected and analyzed the data for his PhD thesis, and wrote the first draft of the paper; A.T.N., M.S., A.K.K., and P.S. helped the PhD student (A.Z.) in data analysis, and in drafting and improving the paper; B.R.N. developed the concept, designed the experiment; H.D. mentored the PhD student (A.Z.) during the field work, and edited the final paper.

Conflicts of Interest: The authors declare no conflict of interest.

\section{References}

1. Janila, P.; Nigam, S.N.; Pandey, M.K.; Nagesh, P.; Varshney, R.K. Groundnut improvement: Use of genetic and genomic tools. Front Plant Sci. 2013, 4. [CrossRef] [PubMed]

2. Jibrin, M.S.; Habu, S.H.; Echekwu, C.A.; Abdullahi, U.S.; Usman, I.S. Phenotypic and genotypic variance and heritability estimates for oil content and other agronomic traits in groundnut (Arachis hypogaea L.). Int. J. Sci. Res. Eng. Stud. 2016, 3, 29-32.

3. Food and Agricultural Organizations of the United Nations (FAOSATAT). Statistical Data Base; Food and Agricultural Organizations of the United Nations: Rome, Italy, 2016.

4. Janila, P.; Ramaiah, V.; Rathore, A.; Upakula, A.; Reddy, R.K.; Waliyar, F.; Nigam, S.N. Genetic analysis of resistance to late leaf spot in interspecific groundnuts. Euphytica 2013, 193, 13-25.

5. Kumar, D.; Kirti, P.B. Transcriptomic and proteomic analyses of resistant host responses in Arachis diogoi challenged with late leaf spot pathogen, Phaeoisariopsispersonata. PLoS ONE 2015, 10, e0117559. [CrossRef]

6. Waliyar, F. Evaluation of yield losses due to groundnut leaf diseases in West Africa. In Proceedings of the Summary Second Icrisat Regional Groundnut Meeting for West Africa, Niamey, Niger, 11-14 September 1990; ICRISAT: Patancheru, India, 1991; pp. 32-33.

7. Okello, D.K.; Monyo, E.; Deom, C.M.; Ininda, J.; Oloka, H.K. Groundnuts Production Guide for Uganda: Recommended Practices for Farmers; National Agricultural Research Organisation: Entebbe, Uganda, 2013.

8. Mayeux, A.H.; Ntare, R.B. Accessions with resistance to foliar diseases, A. flavus/Aflatoxin contamination and rosette disease. Groundnut Germplasm Catalogue 2001, 2, 23, Groundnut Germplasm Project (GGP), BP 6478, Dakar-Etoile, Senegal.

9. Padmaja, D.; Eswari, K.B.; BrahmeswaraRao, M.V.; ShivaPrasad, G. Genetic variability studies in F2 population of Groundnut (Arachis hypogaea L.). Helix 2015, 2, 668-672. 
10. Hugar, A.; Savithramma, D.L. Genetic variability studies for yield and surrogate traits related to water use efficiency in the recombinant inbred line (RIL) population derived from NRCG 12568 X NRCG 12326 of groundnut (Arachis hypogaea L.). Int. J. Agric. Sci. Res. (IJASR) 2015, 5, 321-328.

11. Shrey, A.; Vasanthi, R.P.; Ainmisha, K.; Srivastava, K. Correlation studies in early segregating generation in groundnut (Arachis hypogaea L.). Bioscan 2015, 10, 1975-1979.

12. Bera, S.K.; Kumar, V.; Radhakrishnan, T.; Sojitra, V.K.; Gedia, M.V. Interspecific derivatives for widening the genetic base of groundnut. Indian J. Plant Genet. Resour. 2010, 23, 160-163.

13. Vishnuvardhan, K.M.; Vasanthi, R.P.; Reddy, K.H.P.; Reddy, B.V. Genetic variability studies for yield attributes and resistance to foliar diseases in groundnut (Arachish hypogea L.). Int. J. Appl. Biol. Pharm. Technol. 2012, 3, 390-394.

14. Wambi, W.; Tukamuhabwa, P.; Tirumalaraju, S.V.; Okello, D.K.; Deom, C.M.; Ureta, B.E.B.; Puppala, N. Genetic variability studies of Valencia groundnut varieties for late leaf spot (Phaeoisariopsispersonata) resistance. Afr. J. Plant Sci. 2015, 9, 327-333.

15. John, K.; Reddy, P.R.; Reddy, P.H.; Sudhakar, P.; Reddy, N.P.E. Genetic variability for morphological, physiological, yield and yield traits in F2 populations of groundnut (Arachis hypogaea L.). Int. J. Appl. Biol. Pharm. Technol. 2011, 2, 463-469.

16. Idi Garba, N.M.; Bakasso, Y.; Zaman-Allah, M.; Atta, S.; Mamane, M.I.; Adamou, M.; Hamidou, F.; Idi, S.S.; Mahamane, A.; Saadou, M. Evaluation of agro-morphological diversity of groundnut (Arachis hypogaea L.) in Niger. Afr. J. Agric. Res. 2015, 10, 334-344.

17. Raut, R.D.; Dhaduk, L.K.; Vachhani, J.H. Studies on genetic variability and direct selections for important traits in segregating materials of groundnut (Arachis hypogaea L.). Int. J. Agric. Sci. 2010, 6, 234-237.

18. Padmaja, D.; Eswari, K.B.; BrahmeswaraRao, M.V.; Reddy, M.S. Genetic relationship of yield attributing traits and late leaf spot tolerance with pod yield in BC1F2 population of (JL 24 X ICG 11337) X JL 24 of groundnut. Int. J. Innov. Res. Dev. 2013, 2, 191-196.

19. Gupta, R.P.; Vachhani, J.H.; Kachhadia, V.H.; Vaddoria, M.A.; Reddy, P. Genetic variability and heritability studies in Virginia groundnut (Arachis hypogaea L.). Electron. J. Plant Breed. 2015, 6, 253-256.

20. Kormsa-art, T.; Jogloy, S.; Wongkaew, S.; Lertrat, K. Heritabilities and correlations for late leaf spot resistance and agronomic traits in peanut (Arachis hypogaea L.). Songklanakarin J. Sci. Technol. 2002, 24, 555-560.

21. Shoba, D.; Manivannan, N.; Vindhiyavarman, P. Studies on Variability, Heritability and Genetic Advance in Groundnut (Arachis hypogaeae L.). Electron. J. Plant Breed. 2009, 1, 74-77.

22. Hamasselbe, A.; Sadou, I.; Klassou, C. Genetic variability and correlation among traits explaining resistance to Cercospora leaf spots in groundnut (Arachishypogaea L.). Int. J. Biol. Chem. Sci. 2011, 5, 1135-1142.

23. Ashish, J.; Nadaf, H.L.; Gangadhara, K. Genetic analysis of rust and late leaf spot in advanced generation recombinant inbred lines of groundnut (Arachis hypogaea L.). Int. J. Genet. Eng. Biotechnol. 2014, 5, 109-114.

24. Maurya, M.K.; Rai, P.K.; Kumar, A.; Singh, B.A.; Chaurasia, A.K. Study on genetic variability and seed quality of groundnut (Arachis hypogaea L.) genotypes. Int. J. Emerg. Technol. Adv. Eng. 2014, 4, 818-823.

25. Patil, A.S.; Punewar, A.A.; Nandanwar, H.R.; Shah, K.P. Estimation of Variability parameters for yield and its component traits in groundnut (Arachis hypogaea L.). Bioscan 2014, 9, 749-754.

26. Dolma, T.; Sarkar, M.R.; Reddy, P.R. Genetic variability, correlation and path analysis for yield, its components and late leaf spot resistance in groundnut (Arachis hypogaea L.). J. Oilseeds Res. 2010, 27, 154-157.

27. Sabiel, S.A.I.; Ismail, M.I.; Abdalla, E.; Osman, K.A. Genetic variation of groundnut (Arachis hypogaea) genotypes in semi-arid zone Sudan. Int. J. Environ. 2014, 3, 16-23. [CrossRef]

28. Anderson, W.F.; Holbrook, C.C.; Wynne, J.C. Heritability and early-generation selection for resistance to early and late leaf spot in peanut. Crop Sci. 1991, 31, 588-593. [CrossRef]

29. Nandini, C.; Savithramma, D.L.; Naresh, B.N. Genetic variability for surrogate traits of water use efficiency in F8 recombinant inbred lines of the cross NRCG12568 X NRCG12326 in groundnut (Arachis hypogaea L.). Electron. J. Plant Breed. 2010, 2, 555-558.

30. Korat, V.P.; Pithia, M.S.; Savaliya, J.J.; Pansuriya, A.G.; Sodavadiya, P.R. Studies on characters association and path analysis for seed yield and its components in groundnut (Arachis hypogaea L.). Legum. Res. 2010, 33, 211-216.

31. Gaikpa, D.S.; Akromah, R.; Asibuo, J.Y.; Appiah-Kubi, Z.; Nyadanu, D. Evaluation of yield and yield components of groundnut genotypes under Cercospora leaf spots disease pressure. Int. J. Agron. Agric. Res. $2015,7,66-75$. 
32. Angadi, C.C.; Motagi, B.N.; Naidu, G.K.; Desai, S.A.; Shashidhar, T.R.; Gowda, M.V.C. Genetic variability and association of late leafspot resistance and productivity in groundnut (Arachis hypogaea L.). World Res. J. Biosci. 2013, 6, 145-147.

33. Subrahmanyam, P.; McDonald, D.; Waliyar, F.; Reddy, L.J.; Nigam, S.N.; Gibbons, R.W.; Rao, V.R.; Singh, A.K.; Pande, S.; Reddy, P.M.; et al. Screening Methods and Sources of Resistance to Rust and Late Leaf Spot of Groundnut. Information Bulletin No. 47; ICRISAT: Patancheru, India, 1995; p. 24.

34. Pande, S.; Rao, N.J. Resistance of wild Arachis species to late leaf spot and rust in greenhouse trials. Plant Dis. 2001, 85, 851-885. [CrossRef]

35. Burton, G.W. Quantitative inheritance in grasses. In Proceedings of the 6th International Grassland Congress, Pennsylvania State College, PA, USA, 17-23 August 1952; pp. 227-283.

36. Johnson, H.W.; Robinson, H.F.; Comstock, R.E. Genotypic and phenotypic correlations in soybean and other implications in selection. Agron. J. 1955, 47, 477-483. [CrossRef]

37. Burton, G.W.; De Van, E.H. Estimating heritability in Tall Fescue (Fescuta arundinacea) from replicated clonal material. Agron. J. 1953, 45, 481-487. [CrossRef]

(C) 2017 by the authors. Licensee MDPI, Basel, Switzerland. This article is an open access article distributed under the terms and conditions of the Creative Commons Attribution (CC BY) license (http://creativecommons.org/licenses/by/4.0/). 